\title{
Respon Remaja Lelaki Suka Lelaki (LSL) dengan Status HIV Positif terhadap Pencegahan Penularan HIV kepada Pasangan
}

\author{
Fauziyah $^{*)}$, Zahroh Shaluhiyah ${ }^{* *}$, Priyadi Nugraha $\left.\mathbf{P}^{* *}\right)$ \\ *) Alumni Magister Promosi Kesehatan, Universitas Diponegoro \\ Korespondensi: fauziyahhikmi@gmail.com. \\ **) Magister Promosi Kesehatan, Universitas Diponegoro
}

\begin{abstract}
ABSTRAK
Di Kabupaten Kota jambi kasus HIV positif pada LSL mengalami peningkatan yang berusia antara 19-24 tahun sebanyak 35,1\%. yang berdampak pada pencegahan penularan HIV. Penelitian ini dilakukan pada tahun 2016 dan bertujuan memahami respon LSL remaja dengan status HIV positif terhadap pencegahan penularan kepada pasangan. Metode penelitian kualitatif dengan desain studi kasus. teknik pengambilan sampel dengan cara purposive dan pengumpulan data menggunakan indepth interview. Informan utama adalah remaja LSL yang sudah HIV positif 7 orang. Informan triangulasi kepada ketua Yayasan Kanti Sehati, Ketua kelompok Komunitas, Penjangkau lapangan di Kota Jambi. Hasil penelitian menunjukkan bahwa respon saat pertama kali mengetahui bahwa dirinya terinfeksi HIV positif menolak terhadap status HIV positif respon nya kagek,terkejut,dan tidak percaya meluapkan perasaan emosional dalam bentuk stress dan depresi. pengungkapan status kepada pasangan dan orang terdekat belum semua dilakukan takut terhadap penolakan dari pasangan, Respon terhadap kepatuhan ARV sudah baik. Respon terhadap pencegahan HIV dengan kondom sebagian kecil masih belum konsisten penggunaan kondom karena masih sering menggunakan alkohol. Sedangkan respon terhadap perilaku seksual setelah HIV sebagian kecil belum mampu melakukan pencegahan penularan sesuai standar, sebagian besar masih mengalami Stigma dari keluarga, dan kekerasan fisik dari masyarakat.

Kata Kunci : Respon LSL, remaja, HIV, pencegahan HIV
\end{abstract}

\section{ABSTRACT}

In Jambi City, the cases of HIV-positive in MSM increased in the people aged 19-24 years old by $35.1 \%$. It affected on the prevention of HIV transmission. The research was conducted in 2016 and aimed to understand the response of teenage MSM with the status of HIV-positive to the prevention of transmission to the partner. The research method was qualitative with the design of case study. The sampling technique was purposive sampling with the data collection using in-depth interview. The main informants were teenage MSM with HIV-positive of 7 persons. The triangulation informants were the chief of Kanti Sehati Foundation, the chief of the Community Group of Field Outreach in Jambi City. The resarch results show that the response when they initially found themselves infected by HIV-positive was a rejection to their status of HIV-positive. Their responses were shocked, surprised, and confused. They expressed their emotion in the form of stress and depression. Status revealation to their partners and closest ones had not been performed fully since they were worried about the rejection from their partners. The response to ARV obedience has been good, but the response to HIV prevention using condoms had not been consistent partially because they were mostly under the effect of alcohol. Then, the response to post-HIV behavior, in few people, showed their inability to prevent the transmission based on the standard. Most of them still experienced the stigma from their families, and physical violence from society.

Keywords: MSM response, teenage, HIV, HIV Prevention 


\section{PENDAHULUAN}

HIV dan AIDS masih merupakan masalah kesehatan global termasuk di Indonesia masalah yang berkembang sehubungan dengan infeksi Human Immunodeficiency Virus (HIV) dan Acquired Immuno Deficiency Syndrome (AIDS) adalah angka kejadian dan kematian yang masih tinggi.Penyakit AIDS yang disebabkan infeksi HIV yang menyebabkan hilangnya kekebalan tubuh sehingga penderita mudah terjangkit penyakit infeksi. Sampai akhir tahun 2015 target tidak tercapai atau jumlahnya tidak menurun maka HIV dan AIDS bukan lagi masuk target MDGs tetapi menjadi Suistanable Development Goals (SDGs).(Nasronuddin, 2007)

World Health Organization (WHO) dilaporkan bahwa pada tahun 2012 terdapat 3,5 juta orang di Asia Tenggara hidup dengan HIV dan AIDS. Beberapa Negara seperti Myanmar, Nepal, dan Thailand menunjukkan tren penurunan untuk infeksi baru HIV, hal ini dihubungkan salah satunya dengan diterapkannya program pencegahan HIV dan AIDS melalui program Condom use 100 persen (CUP). Trend kematian yang disebabkan oleh AIDS antara tahun 2002 sampai 2011 berbeda disetiap bagian Negara. Di Eropa Timur dan Asia Tengah sejumlah orang meninggal karena AIDS meningkat dari 7.800 menjadi 90.000, di Timur Tengah dan Afrika Utara meningkat dari 22.000 menjadi 35.000, di Asia Timur juga meningkat dari $24.000 \quad$ menjadi 56.000.(WHO, 2012)

Menurut data dari Direktorat Jendral Penanggulangan Penyakit Menular dan Penyehatan LingkunganKemenkes RIhingga bulan Juni 2011, tercatat anak penderita HIV dan AIDS terdapat 742 kasus. Angka ini terlihat peningkatan dua kali lebih tinggi di bandingkan tiga tahun sebelumnya, yang hanya 351 kasus. Kasus AIDS pada tahun 2012 yang terjangkit pada perempuan ditemukan sebanyak 8.970 kasus. Pencegahan HIV dan AIDS sedini mungkin tak hanya menurunkan jumlah penderitatetapi juga turut membantu pemerintah mencapai Indonesia sehat (MDGS) di tahun 2015.(Kemenkes RI, 2012) Berdasarkan data Komisi Penanggulangan AIDS Nasional tahun 2013, sekitar 77\% penularan HIV dan AIDS terjadi melalui hubungan seks. Hubungan seks baik heteroseksual maupun homoseksual adalah model utama penularan HIV.(Widyastuti, 2009)

Tidak dapat dipungkiri perilaku seksual dikelompok resiko tinggi komunitas homoseksual memberikan kontribusi penularan HIV dan AIDS yang signifikan. Penularan HIV melalui seks anal dilaporkan memiliki 10 kali lebih tinggi dari seks vaginal. Menurut yayasan Riset AIDS Amerika Amfar menyimpulkan kelompok 
homoseksual ternyata berisiko 19 kali lebih besar tertular penyakit HIV dibandingkan masyarakat umum. (Ridwan, 2010)

Masalah psikologis juga merupakan hal yang tidak mudah bagi ODHA. Umumnya ODHA mengalami stress dan depresi, perasaan tertekan dan merasa tidak berguna, bahkan ada yang memiliki keinginan untuk bunuh diri. Seperti yang diungkapkan Joerban. Hampir 99\% penderita HIV/AIDS mengalami stres berat, menemukan sejumlah pasien HIV/AIDS yang mengalami depresi berat, dimana pada saat mengetahui dirinya mengidap penyakit AIDS, banyak ODHA yang tidak bisa menerima kenyataan bahwa dirinya tertular HIV/AIDS, sehingga menimbul-kan depresi dan kecenderungan bunuh diri pada diri ODHA itu sendiri.(Astuti \& Budiyani, 2010)

Kementerian Kesehatan RI menyebutkan bahwa jumlah kumulatif kasus HIV dan AIDS dari awal penelusuran kasus pada April 1987 sampai dengan bulan Juni 2014 sudah terdapat 55.623 kasus, dimana laki-laki berjumlah 29.882 dan perempuan sebesar 16.092, sementara sisanya tidak diketahui identitas seksualnya.Faktor risiko HIV dan AIDS tertinggi ditemukan pada heteroseksual sebesar 34.187,IDU (injection drugs users) sebesar 8.451 kasus dan urutan ketiga tertinggi adalah homoseks dan biseksual sebesar 1.298 kasus.(Kemenkes RI 2014)
Dalam strategi komunikasi penanggulangan HIV dan AIDS di Indonesia, terdapat dua target utama yaitu populasi kunci (key population) dan populasi umum. Populasi Kunci terdiri dari pengguna narkoba suntik atau IDU, Penjaja Seks Perempuan (PSP),laki laki yang berhubungan sek dengan laki laki (LSL), dan waria, serta ODHA.(Kemenkes RI, 2014)

Selanjutnya, Banyak LSL remaja dengan HIV positif menyembunyikan jati dirinya sebagai remaja LSL dengan status HIV positif, dikarenakan secara tidak langsung mereka akan ada penolakan dari pasangan,keluarga, dan lingkungan Diakibatkan oleh masih rendahnya informasi mengenai HIV dan AIDS pada remaja LSL dan masyarakat, mereka rata-rata tidak melanjutkan pendidikan kejenjang yang lebih tinggi, akibat malu dengan status HIVnya. Bagi individu yang positif terinfeksi HIV, menjalani kehidupannya akan terasa sulit karena dari segi fisik individu tersebut akan mengalami perubahan yang berkaitan dengan perkembanganpenyakitnya. Pandangan dan sikap lingkungan terhadap orang yang terinfeksi HIV yang umumnya belum bisa menerima, takut,mendapatkan cap buruk, yang bisa berujung pada pengucilan serta diskriminasi membuat penderita semakin stress. (Soetjinigsih, 2011)

Berdasarkan data yang didapatkan dari KPAP Jambi menunjukkan bahwa HIV di Kota Jambi terjadi peningkatan kasus HIV 
dari tahun ketahun yaitu tahun 2013 sebanyak 116 kasus, tahun 2014 sebanyak 119, tahun 2015127 kasus. Menurut data dari kelompok komuinitas Macam Warna Gay Jambi anggota gay di Kota Jambi sebanyak 213 orang. Untuk data HIV pada kelompok komunitas dari tahun 2013-2015 sebanyak 51 kasus HIV Rentang usia antara 14-50 tahun. Dari kasus yang ada terdapat 19 orang berusia 15-24 tahun sudah terinfeksi HIV positif. (Dinkes Kota Jambi, 2014)

Banyak Penelitian yang telah dilakukan terkait perilaku seksual pada LSL serta faktor-faktor yang mempengaruhi terjadi LSL Namun penelitian tentang LSL remaja dengan status HIV positif diJambi masih jarang dilakukan.Dengan adanya status HIV positif pada masa ini akan menimbulkan berbagai macam respon fisik seperti menurunnya berat badan, demam, sering merasa lemah membuat aktivitas terganggu, maupun respon psikologis oleh remaja itu sendiri, seperti kagek/shock. malu, dan tidak percaya diri, khawatir dan efek samping dari pengobatan, serta adanya stigma dari keluarga, masyarakat dan teman sebaya. Semakin awal remaja LSL dengan status HIV positif semakin beresiko untuk terjadinya penularanHIV kepada pasangan.

\section{METODE}

Penelitian ini menggunakan metode qualitative dengan desain studi kasus untuk memahami respon LSL remaja dengan HIV positif terhadap pencegahan penularan kepada pasangan di Kabupaten Kota Jambi. Pemilihan informan dilakukan secara purposive sampling dengan kriteria: LSL Remaja yang berstatus HIV positif berusia 19-24 tahun, LSL Remaja yang sudah HIV positif dan menjalani pengobatan ARV dan bersedia menjadi informan penelitian. Pengumpulan data dilakukan dengan cara wawancara mendalam, dengan alat bantu berupa panduan wawancara dan perekam suara. Dalam menjangkau informan peneliti dibantu penjangkau lapangan dan perangkat di Yayasan kanti Sehati. Langkah awal dengan melakukan pendekatan dengan ketua Yayasan kanti sehati dan ketua kelompok komunitas untuk mendapatkan data LSL remaja yang bersatatus Hiv positif untuk mendapatkan gambaran umum dari remaja tersebut. Terdapat 10 informan, namun dua informan tidak dapat ditemui karena sudah lost kontak dengan komunitas sulit dilacak keberadaannya, dan satu informan menolak diwawancarai. Sampai akhir penelitian terdapat tujuh informan yang berhasil dilakukan pengumpulan data. Informan triangulasi 3 orang yaitu ketua yayasan Kanti Sehati, ketua kelompok Komunitas, dan penjangkau lapangan. Adapun analisis data dilakukan secara thematic content analysis.(Ghony, 1997). 


\section{HASIL DAN PEMBAHASAN}

\section{A. Karakteristik Informan}

Tabel 1. Karakteristik Informan

\begin{tabular}{|c|l|c|c|c|c|c|c|}
\hline $\begin{array}{c}\text { N } \\
\text { o }\end{array}$ & $\begin{array}{c}\text { Kode } \\
\text { Informan }\end{array}$ & Umur & Pendidikan & Agama & $\begin{array}{c}\text { Pekerjaan } \\
\text { orang tua }\end{array}$ & HIV positif & ARV \\
\hline 1 & Iw- IU1 & 24 & SMP & Islam & Buruh & Awal 2015 & Awal 2015 \\
\hline 2 & Ag-IU 2 & 19 & SMA & Islam & Swasta & Feb 2016 & Maret 2016 \\
\hline 3 & Sg-IU3 & 24 & SMA & Budha & Almr & Feb 2015 & Mar 2015 \\
\hline 4 & Ar- IU4 & 22 & SMA & Islam & Sopirangkot & Jan 2016 & Maret 2016 \\
\hline 5 & Dd-IU5 & 23 & SMA & Islam & Buruh & April 2015 & Agst 2015 \\
\hline 6 & Hr-IU6 & 22 & SMA & Islam & Pedagang & Maret 2015 & Sep 2015 \\
\hline 7 & Ad-IU7 & 23 & SMA & Islam & Swasta & Maret 2016 & Mei 2016 \\
\hline \multicolumn{7}{|l|}{ Tabel 1. Menunjukkan informan utama melakukan sesuatu yang } & menantang. \\
\hline
\end{tabular}

termasuk dalam kategori informan berada (Hurlock, 2004)

pada rentang 19-24 tahun memasuki usia remaja akhir. Remaja tahap ini adalah mendekati masa dewasa yang ditandai dengan minat yang semakin mantap terhadap fungsi-fungsi, egonya mencari kesempat-an bersatu dengan dengan orang lain untuk mendapatkan pengalaman baru, terbentuk indentitas yang tidak berubah lagi. Remaja mulai tampak bebas ingin mencari identitas diri, adanya keingin ketertarikan pada sejenis, ada perasaan cinta, kemampuan berpikir secara abstrak berkembang berkhayal mengenai hal-hal yang berkaitan dengan seksual. masa ini remaja penuh gejolak, termasuk masa interaksi dengan kawan sejenis. Menurut seorang psikolog Elisabeth Hurlock usia remaja merupakan usia pencarian jati diri dengan karakteristik khasnya suka mencoba hal-hal yang baru dan

Berdasarkan tingkat pendidikan, sebagian besar informan berpendidikan SMA.Terbatasnya pendidikan tanpa diiringi keahlian lain membuat informan sulit untuk beradaptasi dengan lingkungan kerja yang formal. Hal ini di buktikan bahwa tingginya tingkat pendidikan informan tidak berpengaruh terhadap pengetahuan mereka tentang seksualitas dan perilaku seksual mereka.(Green, L \& Kreuter, 1991)

Pendidikan perspektif harus di mulai dari rumah. Orang tua mempunyai peran untuk mengajarkan pendidikan seks kepada anak, jika orang tua tidak ada maka pilihan selanjutnya adalah guru yang dapat memberikan pendidikan seputar seks, Seperti di katakan Dostoevsky “ tanpa tuhan, segalanya mungkin terjadi "maksudnya 
kurangnya keimanan dapat mendorong perbuatan yang keliru.(Koes I, 2014)

Pekerjaan orang tua dari informan ratarata bekerja sebagai buruh dan menjadi orang tunggal dengan penghasilan yang tidak tetap, yang membuat mereka tidak mencukupi kebutuhan hidup secara ekonomi dan keluarga yang broken home. Pada hakekatnya keluarga yang diharapkan mampu berfungsi untuk mewujudkan proses pengembangan timbal balik rasa cinta dan kasih sayang antar anggota keluarga, antar kerabat, serta antar generasi yang merupakan dasar keluarga yang harmonis. Sebaliknya pada keluarga yang tidak harmonis, dimana tidak ada lagi cinta dan kasih sayang maka hidup seakan akan hampa sehingga mengakibatkan hilangnya semangat kerja dan produktivitas.(Green, L \& Kreuter, 1991)

\section{Orientasi seksual}

Peneliti memulai penelusuran tentang awalnya infoman menyadari dan menyukai sesama jenis dan bergabung dengan kelompok komunitas MWGJ sampai dengan mengetahui dirinya HIV positif. Jawaban yang diberikan informan hampir sama yaitu sejak kecil merasa bawaan lahir, dan di pengaruhi dan diajak dan meihat teman yang melakukan hubungan seks dengan teman laki-laki serta karena di ajari oleh yang lebih dewasa dari informan. Namun mereka tidak pernah mencerita atau membicarakan kepada orang-orang yang terdekat dengan mereka misal orang tua,keluarga kandung,dengan berbagai alasan mereka diantaranya takut, malu, khawatir, tawar, dan depresi. Hal ini mengacu pada pandangan individu tentang identitas pribadinya yang dirasakan berbeda dari orang lain. Meskipun menyadari identitas pribadinya sejak kecil, pengalaman traumatis juga mendorong informan untuk disorientasi seksual.(Amaliyasari, 2008)

\section{Perilaku seksual}

Perilaku homoseksual dapat yang diawali masa kanak-kanak yang disebabkan oleh gangguan perkembangan seksual seseorang (psikoseksual pada masa kanakkanak) serta ditambah pengaruh hubungan orang tua yang tidak harmonis. Dalam perkembangan remaja homoseksual bukan lagi sebagai gangguan kejiwaan tetapi bisa timbul akibat pola asuh orang tua dalam keluarga, faktor lingkungan juga yang mendorong seseorang untuk berperilaku homoseksual. Faktor lingkungan sosial misalnya tempat tinggal, pergaulan bebas, pengaruh teman sebaya, dan sering bergabung dalam kelompok komunitas, seperti di cafe-cafe atau tempat-tempat tertentu yang menjadi trend bagi mereka. (Paryati, 2010)

\section{Alasan melakukan Test HIV}

Hasil penelitian bahwa alasan informan melakukan test HIV untuk 
mengetahui apakah dirinya terinfeksi HIV positif atau tidak, karena dirinya menganggap selama ini berperilaku seksual yang berisiko, setelah menjalani perjalanan hidup informan yang melakukan hubungan seksual dengan banyak pasangan tanpa menggunakan kondom dan pelicin, Dalam penelitian ini juga ditemukan bahwa pelaksanaan VCT pada kelompok remaja LSL belum semua informan menjalani test HIV dengan kesadaran sendiri dan berjalan dengan baik. Hal ini di ungkap oleh informan bahwa mereka sudah melakukan tes HIV itu secara paksa dan bukan sukarela, karena dari tujuh orang informan yang melakukan tes HIV dua orang diantaranya melakukan test bukan berdasarkan atas kesadaran sendiri tetapi atas paksaan secara pengetahuan informan belum memahami dan prosedur dan mamfaat serta tujuan tentang VCT informan belum mendapatkan konseling sebelum dan sesudah test HIV baik oleh LSM, komunitas,sendiri maupun Puskesmas. Padahal, Untuk Prosuder pelayanan konseling dan testing HIV adalah sukarela pemeriksaan HIV hanya dilaksanakan atas dasar kerelaan klien, tanpa paksaan dan tanpa tekanan. Saling mempercayai dan terjamin konfiedensialitas.

Hal inisesuai yang diungkapkanDemartoto terkait motif ataupun motivasi yang melatarbelakangi usaha yang dilakukan LSL dalam rangka menjalankan tindakan Voluntary Counseling and Testing
(VCT) hasil yang didapat dalam penelitian ini adalah bahwa tidak semua LSL mempunyai motivasi dan keberanian yang sama dalam melakukan tindakan Voluntary Counseling and Testing (VCT).(Dermatoto A, 2010)

Berdasarkan hasil wawancara dengan dengan ke tujuh informan dilakukan content analysis secara keseluruhan yang mengacu pada tujuan penelitian dan menghasilkan lima tema utama yaitu Respon terhadap status HIV positif. Respon terhadap terapi ARV, Respon terhadap pencegahan HIV dengan kondom, Respon terhadap perilaku setelah HIV positif, Respon terhadap stigma yang di hadapi. Kelima tema utama tersebut merupakan hasil identifikasi dari jawaban beberapa item pertanyaan yang mengambarkan keseluruhan tema yang diteliti.

\section{B. Hasil Analisis Data Penelitian}

\section{Respon Menolak Terhadap HIV/AIDS}

Pada penelitian ini didapatkan respon yang beragam dari partisipan saat mengetahui dirinya terdiagnosis HIV/AIDS Semua informan saat pertama kali terdiagnosis HIV/AIDS berespon menolak terhadap keadaannya tersebut. Menolaknya informan didiagnosis HIV/AIDS dapat berupa menyangkal (tidak percaya, kaget/Shock, takut, dan marah), tawar menawar (pengandaian), maupun depresi (menarik diri, khawatir akan masa depan dan 
perasaan sedih terhadap keadaan yang dialami). seperti yang dialami oleh informan.

“Ya...saya kanget banget...siapa yang mau punya penyakit HIV ... masih belum percaya apa yang dikasih tau jangan-jangan salah hasil, atua salah pemeriksaan....." (Ad,IU623 tahun)

Hal tersebut terjadi karena informan merasa belum siap dan merasa tidak mungkin menderita penyakit HIV/AIDS serta tidak percaya hal ini bisa terjadi pada dirinya, walaupun sebelumnya tiga dari informan sudah mengetahui bahwa dirinya memiliki faktor resiko. Hal ini dipertegas oleh KublerRoss1969, dalam Suratini 2011) menyatakan bahwa reaksi pertama individu terhadap kehilangan adalah tidak percaya, terkejut, merasa terpukul, dan menyangkal. Secara sadar maupun tidak sadar seseorang yang berada dalam tahap ini menolak semua fakta, informasi dan segala sesuatu yang berhubungan dengan hal yang dialaminya. Individu merasa hidupnya tidak berarti lagi. (Suratini, 2013)

Hal ini didukung oleh pendapat vinen dalam Suratini, pada tahap depressi individu akan mengalami disorganisasi dan merasa tidak mampu melakukan tugas dengan sedikit kesulitan. Orang pada tahap ini akan memilki kesedihan yang mendalam. Depresi dan kegelisahan dialami oleh sebagian yang sangat besar pada pasien HIV/AIDS. Sekitar
$72 \%$ mengatakan mereka mengalami depresi, $65 \%$ mengalami kegelisahan dan $48 \%$ insomnia.(Suratini, 2013)

\section{Respon Menerima Terhadap HIV/AIDS}

Seiring berjalanannya waktu dan ditambah dengan adanya dukungan dari keluarga kelompok komunitas baik yang sudah terdiagnosa maupun yang belum dari teman sebaya di komunitas MWGJ terdapat respon penerimaan pada semua informan terhadap diagnosis HIV/AIDS. Adapun bentuk respon penerimaan terdiagnosis HIV/AIDS adalah kepasrahan dan ketegaran dengan keadaannya saat itu.

"Saya bersikap pasrah kepada allah terhadap diri saya yaitu saya akan memperbaiki diri saya dan berfikir positif banyak kok yang sudah HIV positif tapi ada yang tetap sehat.."(Iw,IU1-24 tahun)

Berdasarkan data diatas Informan mulai menerima semua kenyataan dengan melihat sesuatu yang terjadi pada dirinya merupakan hal yang dapat dijadikan pelajaran bagi kehidupan informan dimasa depan dan mengganggap bahwa kalau tidak dirinya yang berusaha untuk sehat siapa lagi.Penerimaan ini sangat berkaitan erat dengan aspek spiritual informan yang beragama islam, yang selalu melihat setiap permasalah memiliki hikmah dibaliknya. Penerimaan ini juga diperngaruhi oleh 
strategi koping yang dilakukan informan, semakin lama ODHA terkena penyakit dalam dirinya akan muncul strategi koping. Hal ini sesuai dengan yang diungkapkan Kubler Ross (1974) dalam Nursalam, seiring berjalannya waktu seseorang mulai dapat beradaptasi dengan keadaan serta berkurangnya kepedihan yang menyakitkan. Penerimaan setelah beberapa lama, seseorang dengan HIV biasanya mulai bisa menerima keadaanya. Ini akan membantu membuat merasa lebih baik. Seperti halnya seseorang yang sudah lebih tenang pikirannya, akan mulai memikirkan jalan terbaik dalam menjalani kehidupan.(Nursalam, 2007)

\section{Respon Terhadap Terapi ARV}

Berkaitan dengan kepatuhan mengkomsumsi ARV tidak semua informan begitu didiagnosa HIV melanjutkan dengan pengobatan karena masih ada diantara 7 orang informan 1 orang yang harus membutuh waktu 3 bulan kemudian baru mengkomsumsi ARV karena malu, takut akan ketahuan oleh orang tua karena ia menderita HIV positif. Menurut beberapa informan dampak positif seperti tetap sehat dan tetap bisa bertahan untuk hidup.seperti yang diungkapkan oleh informan

"Saya minum obat teratur karena saya menyadari untuk bisa bertahan hidup....tidak sakit, virus tidak bertambah, badan bisa kuat, kalau tidak patuh percuma jadi tidak kebal lagi terhadap virus alhamdulillah sejauh ini saya tetap sehat dan jauh lebih baik.dan hidup merasa berarti..." (Hr-IU623 tahun).

Namun bagi yang baru menjalani pengobatan mendapatkan dukungan dari ketua komuintas, teman teman yang duluan menjalani pengobatan serta dapat dukungan dari keluarga bagi informan yang telah membuka status HIV positif dan menjalani pengobatan.Ketidak patuhan ARV akan membuat proses terapi pengobatan ARV mengalami resistensi terhada obat ARV. Temuan tersebut didukung oleh Steel, Nwokike (2007) bahwa faktor yang berhubungan dengan kepatuhan antara lain adalah pengetahuan, faktor sikap (persepsi yang mahal tentang kepatuhan), kompleksitis regimen yang digunakan, keadaan sakit yang dirasakan, faktor lingkungan (keterjangkauan klinik, transpostasi) dan faktor psikis (depresi).Green (2000) menyatakan pengetahuan merupakan dasar dari perilaku yang menyediakan alasan utama atau motivasi untuk berperilaku. Apabila memiliki pengetahuan yang tinggi tentang terapi ARV makan mempunyai kemungkinan untuk melaksanakan kepatuhan yang tinggi. (Green, L \& Kreuter, 1991)

\section{Respon Terhadap Pencegahan dengan}

\section{Kondom}

Penelitian ini menemukan semua Remaja LSL dengan status HIV positif 
berusaha untuk menggunakan kondom setiap melakukan hubungan seks, mereka menyadari dengan menggunakan kondom bisa mencegah penularan HIV. Ternyata dalam penelitian hanya berusaha tanpa di dasari oleh tindakan tidak cukup menjamin upaya remaja LSL dalam memakai kondom sebagai pencegahan HIV positif, karena ada sebagian besar remaja LSL ditemukan dalam penelitian ini masih melakukan hubungan seksual dengan tidak menggunakan kondom. Adanya negosiasi dalam penggunaan kondom, ketidak ketersedian kondom, rasa tidak nyaman, dan tidak nyakin tentang efektifitas kondom dalam pencegahan HIV positif. 1 orang informan masih belum bisa mengendalikan diri karena seks yang tidak terencana, 1 orang informan tidak bisa mengontrol dirinya karena sering menggunakan minum alkohol.

“eemm.. saya berusaha selalu pakai kondom tapi kadang suka lepas kontrol kalau tibatiba ada teman telepon ngajak...pas lupa bawa kondom kira-kira 3 hari yang lalu lah ya nggk pakai .. susah kadang suka lepas kontrol gitu juga tidak bawa kondom... 'aku sama pasangan satu minggu ini masih makai kondom..." (Ags,IU2-19 tahun)

Perilaku pemakaian kondom tidak hanya dipengaruh oleh pengetahuan dan informasi belajar dan perkembangan emosi, sikap tetapi masih ada faktor lain yang berpengaruh yaitu faktor karakteristik perilaku beresiko seperti menggunakan alkohol. Menurut Wijaya 2009,Komsumsi alkohol dan obat terlarang dapat mempengaruhi terhadap kesehatan seksual, pemakaian obatterlarang dapat juga memudahkan orang memaksa seseorang melakukan perilaku seksual yang dalam keadaan sadar tidak akan dilakukan. Orang juga bisa tidak selektif memilih pasangan seksual dan orang berhubungan seksual dibawah pengaruh alkohol lebih besar kemungkinan melakukan perilaku seksual beresiko atau tanpa pelindung. Menurunkan batasan dan dapat membuat seseorang sukar memakai kondom dengan benar maupun sulit meminta pasangannya menggunakan kondom. Terkait saat berhubungan aktivitas seks, bahwa belum semua informan konsisten dalam penggunaan kondom. Informan hanya menggunakan kondom pada saat tertentu, seperti melakukan seks anal, sedangkan pada sek oral informan tidak menggunakan kondom alasannya oral seks tidak berbahaya. Sedangkan pada anal seks akan menimbulkan perlukaan atau lecet pada daerah rectum sehingga mempermudah terjadi penularan infeksi HIV.(Nurwijaya $H$, 2009)

Upaya yang dilakukan adalah menyedia kondom, berkomitmen dengan diri sendiri untuk memakai kondom secara konsisten, serta terus memotivasi diri dengan segala kenyakinan yang mereka miliki. Dukungan dari pasangan dan lingkungan 
sekitar juga mempengaruhi seseorang untuk melakukan tindakan pencegahan HIV dan AIDS. Dukungan sosial adalah pemberian bantuan dalam bentuk verbal maupun non verbal seperti kasih sayang, perhatian, penilain dan nasehat yang berdampak positif bagi individu. Dukungan sosial didapatkan individu dari hubungan dengan orang lain dalam suatu jaringan sosial yang dapat diandalkanya.(Khalid, 2011)

\section{Respon Perilaku pada LSL Setelah HIV Positif}

Respon tehadap perilaku seksual LSL setelah didiagnosa HIV positif. Dalam penelitian ini masih ada yang melakukan hubungan seksual dengan tidak menggunakan kondom. Hal ini perlu dijadikan alasan tentang perlunya upaya yang dilakukan dan perilaku seksual yang sehat di kalangan remaja LSL. Adanya informan yang terinfeksi HIV positif dan berhubungan seks yang tidak aman, sehingga besarnya peluang menular kepada pasangan dan tertular infeksi HIV dan AIDS. Seperti diketahui bahwa remaja LSL yang sudah positif HIV rentan berpeluang terinfeksi virus lain selain HIV dan AIDS.

"Semenjak di kasih tau HIV positif saya selalu berusaha untuk tidak ganti-ganti pasangan lagi saya milih punya pasanngan tetap. sudah punya pasangan tetap..sekarang setelah HIV saya tidak lagi sembarangan saya hanya teman dekat yang itu-itu saja" (Hr,IU6-23 tahun)

Namun dukungan teman sebaya dan pasangan selain keluarga juga menjadi salah bentuk tempat bersosialisasi dalam kehidupan individu, pasangan, teman dan sahabat juga termasuk yang memberikan pengaruh bagi informan dalam melakukan perubahan perilaku seksual setelah HIV positif. Teman dan sahabat sangat dibutuhkan oleh LSL remaja karena sebagai salah satu pihak yang memberikan dukungan ketika seseorang mengalami suatu persoalan. Untuk merubah perilaku pada seseorang yang telah didiagnosa HIV positif yaitu dengan peningkatan pengetahuan dan kesadaran terhadap HIV positif yaitu dengan melakukan strategi khusus kepada kelompok sasaran primer seperti LSL yang berisiko tinggi. Prinsip perubahan perilaku bahwa jika seseorang tahu dan mempunyai pengetahuan dan informasi secara terus menerus dan berkesinambunga yang memadai tentang kesehatan dan mempunyai kesadaran yang mendukung perubahan perilaku, seperti setuju terhadap tindakan pencegahan dengan menggunakan kondom secara konsisten pada setiap kali hubungan seks maupun tindakan lainnya.(Dermatoto A, 2010)

Penelitian ini sama dengan penelitian yang dilakukan oleh Aditya tentang perilaku berganti ganti pasangan tanpa adanya pemakaian kondom yang konsisten, yang 
demikian sangat memungkinkan terjadinya transmisi penyakit menular seksual. Karena pasangan mareka tidak di ketahui riwayat dan status kehidupan seksual sebelumnya. Jaringan seksual yang luas ini juga meningkatkan resiko penularan HIV pada LSL dan pasanganyaan sesama jenis.(Aditya ER, 2014)

\section{Respon Terhadap Stigma yang di Hadapi}

Stigma biasanya diakibatkan karena ketidaktahuanya masyarakat tentang informasi HIV yang benar dan lengkap, khususnya dalam mekanisme penularan HIV. Dampaknya informan harus menanggung beban semakin berat, tidak saja intervensi HIV dalam tubuhnya tetapi juga psikologis. Dalam hidup bermasyarakat, stigma juga menghalangi seseorang untuk melakukan aktivitas sosial. orang dengan status HIV menutup diri dan cenderung tidak bersedia melakukan interaksi dengan keluarga, teman, dan tetangga dan kekerasan fisik yang dialaminya.

"Saya dipukulin sama orang-orang alasan karena melanggar hukum adat setempat dan dan dijanjika akan dilapor kepada polisi kalau aku tidak membayar adat...sebenarnya saya dijebak melakukan hubungan sek sejenis dan salah satu dari klien saya LSL yang lebih senior dan mengetahui kalau saya HIV positif..marah katanya saya menular
HIV itu kepada orang lain..saya harus membayar adat..". (Sgt,IU3-24 tahun)

Hal ini disebabkan karena sebagian masyarakat beranggapan bahwa orang dengan HIV positif adalah orang berperilaku tidak baik. Akibat stigma mereka tidak diterima baik dari keluarga maupun masyarakat. Hal ini dapat diamati dari sikap masyarakat yang tidak peduli terhadap orang dengan HIV positif. Selanjutnya stigma dan diskriminasi juga merupakan penghambat dalam upaya penanggulangan HIVdan AIDS. Adanya stigma sosial dan diskriminasi telah menyebabkan sebagian masyarakat yang pernah melakukan perilaku berisiko merasa khawatir, takut dan malu serta dikucilkan oleh keluarga dan masyarakat setelah di vonis HIV positif. Mengungkapkan bahwa adanya pemaknaan negarif terkait dengan stigma yang dapat menyebabkan ketidakpatuhan ODHA dalam minum obat. Selain itu adanya perasaan takut diketahui oleh orang lain atau pasangan atau masyarakat sekitar juga menjadi penghambat kepatuhan minum obat.(Yuniar,Yuyun, 2013)

Adanya stigma pada orang dengan HIV positif adalah apabila seseorang berfikir bahwa HIV positif merupakan penyakit yang sangat berbahaya apabila tertular. kemudian, budaya dimana ia tinggal menganggap bahwa paling rentan dan mungkin terinfeksi adalah kalangan kalangan Gay, masyarakat 
memandang bahwa kelompok gay atau waria yang memang berperilaku berisiko untuk tertularnya HIV positif, perlu dihindari, seperti diri mereka menghindari dari HIV/AIDS. (Herek GM, 1999)

\section{SIMPULAN}

Respon saat pertama mengetahui HIV positif sebagian besar informan menunjukkan respon yang sama yaitu kagek,terkejut dan shock,tidak percaya dan menolak terhadap hasil tes HIV bentuk penolakan seperti stres, depresi, setelah didiagnosa HIV positif. Seiring berjalannya waktu informan menerima dirinya sebagai penderita HIV positif dalam bentuk pasrah dan tegar. Sebagian besar belum mengungkapkan status HIV terutama kepada pasangan dan keluarga karena takut terhadap penolakan dan stigma. Respon terhadap pengobatan dan pencegahan HIV dengan kondom sudah baik namun masih sebagian kecil penggunaan kondom belum konsisten dan ganti-ganti pasangan serta sebagian besar infoman menerima stigma dan diskriminasi dari keluarga dan lingkungan.

Perlunya memberikan informasi kepada remaja LSL dan mengubah cara pandang penderita HIV positif yang selama ini dianggap negatif, menjadi pandangan yang positif meningkatkan pengetahuan, memberikan dukungan moril agar dapat menerima status sebagai penderita HIV, memberikan motivasi serta pendampingan bagi mereka yang sudah HIV terutama yang belum mendapatkan dukungan dari pasangan agar dapat mencegah penularan HIV kepada pasangannya menghilangkan stigma agarmudah mendapatkan akses pelayanan kesehatan. Dinkes Perlu ada program yang melibatkan lintas program yang terkait.

\section{KEPUSTAKAAN}

Aditya ER. Perilaku penggunaan kondom Secara Konsisten untuk pencegahan HIV: Suatau Studi kasus Kualitattif pada Pekerja seks laki laki Berbasis panti Pijat jakarta. 2014.

Amaliyasari, Y.A.N.P. (2008). Perilaku Seksual Anak Usia Pra Remaja di Sekitar Lokalisasi Dan Faktor Yang Mempengaruhi. Jurnal Penelitian Dinas Sosial. 56-60.

Astuti \& Budiyani. (2010). Hubungan antara dukungan sosial yang diterima dengan kebermaknaan hidup pada ODHA. Jurnal Psikologi Universitas Mercu Buana Yogyakarta. Diunduh pada tanggal 19 Februari 2013.http://fpsi.mercubuanayogya. ac.id.

Demartoto,Argyo. 2010, Perilaku Laki-Laki Yang Berhubungan Seks Dengan LakiLaki (LSL) Untuk Melakukan Test HIV di Kota Surakarta, Surakarta. FISIP UNS.

Dinkes Kota Jambi. Profil Kesehatan Kota Jambi. 2014. 
Ghony, D. (1997) Dasar - Dasar Penelitian Kualitatif. Surabaya: PT. Bina Ilmu.

Green, L \& Kreuter M. Health Promotion Planning An Educational and Environmental Appoarch. Second Edition, Mayfield Publising Company Mountain View Toronto London; 1991. Herek GM. CJ. Public Reactions to AIDS in The United States: A Second Decade of Stigma. Am J Public Health. 1999.

Hurlock E. Psikologi Perkembangan: Suatu pendekatan Sepanjang Rentang Kehidupan. Jakarta: Alih Bahasa Isti Widayanti dan Soedjarwo Erlangga; 2004.

Kemenkes RI. Laporan Kasus HIV dan AIDS Indonesia. Jakarta; 2012.

Kemenkes RI. Strategi Komunikasi Penanggulangan HIV dan AIDS di Indonesia. Jakarta: Direktorat Jendral P2P1 Kemenkes RI; 2014.

Khalid, Idham. 2011. Pengaruh Self Esteem Dan Dukungan Sosial Terhadap Optimisme Hidup Penderita HIV/AIDS.

http://repository.uinjkt.ac.id

Agustus 2014,Pukul 19.00).

Koes I. Seksiologi Kesehatan [Internet]. 2014. Available from: www.Cvalfabeta.com.

Nasronuddin. HIV dan AIDS Pendekatan Biologi Molekuler, Klinis, dan Sosial. Surabaya: Airlangga University Press. 2007.
Nursalam, Kurniawati, N,D. Asuhan Keperawatan Pada Pasien Terinfeksi HIV/AIDS. Jakarta : Salemba Medika. 2007.

Nurwijaya H. Bahaya Alkohol. Jakarta:

PT. Elex Media Komputindo. 2009.

Paryati, Tri dan Andini S. Raksanagara. 2010. Gambaran Gaya Hidup (Life Style) Berisiko di Kalangan Kaum Homoseksual (Gay) di Kota Medan. Jurnal Kesehatan Masyarakat Vol.01, No.02 Hal 111. Medan: Bagian Ilmu Kesehatan Masyarakat, Fakultas Kesehatan Masyarakat USU.

Ridwan, Eka Sari, (2010) Perilaku Waria Dalam Upaya pencegahan HIV dan AIDS di Kabupaten Bulukumba htt://id.proposalkualitatifhivaids/index. htm 1 (22 Desember 2013,pukul 19.00).

Soetjinigsih. Tumbuh Kembang Remaja dan Permasalahannya. Jakarta: Sagung Seto; 2011.

Suratini, Pengalaman Orang Dengan HIV/AIDS (ODHA) Mendapatkan Perawatan keluarga Di Wilayah kabupaten kulon Progo Daerah Istimewa Yogyakarta Studi Fenomenologi, tesis Di unduh pada Tanggal 5 April 2013. http;/repository UI.co.id.

WHO. Number of People All Ages Livving With HIV Situation, And 
Jurnal Promosi Kesehatan Indonesia Vol. 13 / No. 1 / Januari 2018

Trends,Genewa. Word Health Organization. 2012.

Widyastuti, E, S, Personal dan Sosial yang Mempengaruhi Sikap Remaja terhadap Hubungan seks Pranikah Jurnal Promosi Kesehatan Indonesia .75-85. 2009.

Yuniar,Yuyun,dkk, "Faktor-faktor pendukung kepatuhan Orang Dengan HIV/AIDS dalam Minum Obat Antiretroviral di Kota Bandung dan Cimahi” Artikel penelitian pada Buletinpnelitian Kesehatan, Vol,41 No,2 Juni 2013. Jakarta .balitbangkes. 